Research article

\title{
Effect of organic fertilizers on the performance of seed potato
}

\author{
R. K. Sikder ${ }^{1}$, M. M. Rahman ${ }^{1}$, SM Washim Bari ${ }^{2}$ and H. Mehraj ${ }^{3,4 *}$ \\ ${ }^{1}$ Horticulture Development Division, BADC, Dhaka-1000, Bangladesh \\ ${ }^{2}$ Seed Testing Laboratory, BADC, Dhaka-1216, Bangladesh \\ ${ }^{3}$ The United Graduate School of Agricultural Sciences, Ehime University, Matsumaya-shi, \\ Ehime 790-8556, Japan \\ ${ }^{4}$ Lab of Vegetable and Floricultural Science, Faculty of Agriculture and Marine Science, Kochi University, \\ Monobe 200, Nankoku-shi, Kochi 783-8502, Japan
}

*Corresponding Author: hmehraj02@yahoo.com

[Accepted: 03 March 2017]

\begin{abstract}
The experiment was conducted for the evaluation of the performance of seed potato to organic fertilizers. Two potato varieties viz. Asterix $\left(\mathrm{V}_{1}\right)$ and Diamant $\left(\mathrm{V}_{2}\right)$ were subjected to different inorganic fertilizers viz. Control $\left(\mathrm{T}_{1}\right)$, Cowdung $\left(\mathrm{T}_{2}\right)$, Annapurna organic fertilizer $\left(\mathrm{T}_{3}\right)$, $75 \%$ Annapurna organic fertilizer $+25 \%$ Vermicompost $\left(\mathrm{T}_{4}\right)$ and Vermicompost $\left(\mathrm{T}_{5}\right)$. Early $80 \%$ emergence was found from $\mathrm{T}_{1}\left(\mathrm{~V}_{1}: 26.3\right.$ days; $\mathrm{V}_{2}: 23.3$ days) while early tuberization from $\mathrm{T}_{2}$ for $\mathrm{V}_{1}$ (36.0 days) and $\mathrm{T}_{1}$ for $\mathrm{V}_{2}$ (29.0 days). Both varieties performed differently to the organic fertilizers used in the experiment. $\mathrm{T}_{4}$ was the best for $\mathrm{V}_{1}\left(14.3 \mathrm{~kg}\right.$ per plot and 28.8 t.ha $\left.^{-1}\right)$ while $\mathrm{T}_{3}$ was best for $\mathrm{V}_{2}\left(14.1 \mathrm{~kg}\right.$ per plot and $\left.28.3 \mathrm{t}^{-\mathrm{ha}^{-1}}\right)$. Asterix yielded more tuber than diamant variety. The performances of both varieties were not varied significantly among the treatments for different graded tuber except for $28-55 \mathrm{~mm}$ graded tuber in asterix. From the study it is suggested to use of $75 \%$ Annapurna organic fertilizer $+25 \%$ Vermicompost for asterix variety with BARI recommended inorganic fertilizers in order to get more yielding seed potato.
\end{abstract}

Keywords: Annapurna - Vermicompost - Asterix - Diamant - Yield.

[Cite as: Sikder RK, Rahman MM, Bari SMW \& Mehraj H (2017) Effect of organic fertilizers on the performance of seed potato. Tropical Plant Research 4(1): 104-108]

\section{INTRODUCTION}

Potato (Solanum tuberosum) is the $3^{\text {rd }}$ (just after rice and wheat) most consumed food crop in the world (Champouret 2010, Verzaux 2010, Visser et al. 2009). The growth and yield of potato largely depends on the soil and soil conditions can be improved throughout the use of different organic fertilizer. Approximately $4 \%$ organic matter is essential of any agricultural soil while soil of our $60 \%$ cultivable land contains organic matter below 1\% (Ferdoushi et al. 2010). Deficiencies of soil organic matter reduced the crop yield which is in important fact for Bangladesh's agriculture. Bangladeshi farmers generally used the inorganic fertilizers judiciously to get high yield and this judicious application of the inorganic fertilizers destroy our agricultural soil. Now it is important to concern about the soil health. Though single nutrient source may supply the respective required nutrients for plant but integrated use of all sources is required for balanced plant nutrition (Arora 2008). Vermicompost used as a fertilizer and soil conditioner (Munroe 2007, Rajesh et al. 2003) responsible for the improvement of the physical properties of soil and supply vital plant nutrients (Smith et al. 2014). Tuber yield of potato is much more after using organic manures than the recommended dose of inorganic fertilizers only (Boke 2014). Balance fertilization is required for most of the crops also for potato (Alam et al. 2007, Sharma et al. 2003) but tuber yield increases with the application of high amount of manures (Roy et al. 2001, Fageria et al. 1997, Johnston 1986). Lack of quality seed potato and high yielding varieties with poor agricultural management was the key factor for low yield of potato (Amede et al. 2006, Mehdin et al. 2000). The hypothesis tested in this study to improve the tuber yield using organic fertilizers. Organic fertilizers were supplemented with adequate nitrogen in available form for plant (Atiyeh et al. 2000, Bayite-Kasule 2009). The current study was done to evaluate the growth and yield performance of seed potato throughout the application of organic fertilizers. 


\section{MATERIALS AND METHOD}

An experiment was conducted at Domar Foundation Seed Potato Production Farm, BADC, Nilphamari, Bangladesh. Two potato varieties viz. Asterix $\left(\mathrm{V}_{1}\right)$ and Diamant $\left(\mathrm{V}_{2}\right)$ were assigned to different inorganic fertilizers viz. Control $\left(\mathrm{T}_{1}\right)$, Cowdung $\left(\mathrm{T}_{2}\right)$, Annapurna organic fertilizer $\left(\mathrm{T}_{3}\right), 75 \%$ Annapurna organic fertilizer $+25 \%$ Vermicompost $\left(\mathrm{T}_{4}\right)$ and Vermicompost $\left(\mathrm{T}_{5}\right)$ using three replication. In total 60 tubers (in three rows i.e., 20 tubers/row) were planted on $2.0 \mathrm{~m} \times 2.5 \mathrm{~m}$ plot. The row to row distance was $60.96 \mathrm{~cm}$. The tuber size ranged from 20-40 mm and tuber to tuber distance was $12.7 \mathrm{~cm}$. Urea, TSP, MP, gypsum and zinc sulphate were applied @ 220,120, 220, 100 and 10 kg.ha ${ }^{-1}$ as basal dose (BARI 2011). Half of urea and entire dose of the rest inorganic fertilizers were applied during final land preparation. Rest half of urea was applied at 30 days after planting. Data were collected on different parameters and analyzed by MSTAT-C computer package program. Means for all the treatments were calculated and the analysis of variance for each of the character was performed by F (variance ratio) test. Data are presented as the mean \pm standard error (SE). Difference between treatments was evaluated by least significant difference (LSD) test at $1 \%$ level of significance (Gomez \& Gomez 1984).

\section{RESULTS}

Day to $80 \%$ emergence and tuberization: Days to $80 \%$ emergence was varied significantly among the treatments in both varieties. Early $80 \%$ emergence was found from $\mathrm{T}_{1}\left(\mathrm{~V}_{1}: 26.3\right.$ days; $\mathrm{V}_{2}: 23.3$ days) while late $80 \%$ emergence was found from $\mathrm{T}_{4}\left(\mathrm{~V}_{1}: 29.7\right.$ days; $\mathrm{V}_{2}: 26.0$ days) (Table 1). Days to tuberization were statistically identical among the treatments in both varieties. However, earliest tuberization was found in $T_{2}$ for $\mathrm{V}_{1}$ (36.0 days) and in $\mathrm{T}_{1}$ for $\mathrm{V}_{2}$ (29.0 days) (Table 1$) . \mathrm{V}_{2}$ showed early $80 \%$ emergence and tuberization than $\mathrm{V}_{1}$.

Plant height: Plant height was varied significantly among the treatments. The tallest plant was found from $\mathrm{T}_{4}$ $\left(\mathrm{V}_{1}: 63.4 \mathrm{~cm} ; \mathrm{V}_{2}: 63.3 \mathrm{~cm}\right)$ while the shortest plant was found from $\mathrm{T}_{1}\left(\mathrm{~V}_{1}: 61.5 \mathrm{~cm} ; \mathrm{V}_{2}: 56.7 \mathrm{~cm}\right)($ Table 1).

Table 1. Effect of different fertilizer on days to $80 \%$ emergence, days to tuberization and plant height of two potato varieties.

\begin{tabular}{|c|c|c|c|c|c|c|}
\hline \multirow{2}{*}{ Treatments } & \multicolumn{2}{|c|}{ Days to $80 \%$ emergence } & \multicolumn{2}{|c|}{ Days to tuberization } & \multicolumn{2}{|c|}{ Plant height $(\mathrm{cm})$ at 60 DAP } \\
\hline & $V_{1}$ & $\mathbf{V}_{2}$ & $V_{1}$ & $\mathbf{V}_{2}$ & $V_{1}$ & $\mathbf{V}_{2}$ \\
\hline $\mathrm{T}_{1}$ & $26.3^{b} \pm 0.19$ & $23.3^{\mathrm{c}} \pm 0.38$ & $36.3^{a} \pm 0.19$ & $29.0^{\mathrm{a}} \pm 0.07$ & $61.5^{\mathrm{c}} \pm 0.33$ & $56.7 d \pm 1.58$ \\
\hline $\mathrm{T}_{2}$ & $27.2^{\mathrm{b}} \pm 0.19$ & $24.0^{\mathrm{bc}} \pm 0.33$ & $36.0^{\mathrm{a}} \pm 0.07$ & $29.3^{\mathrm{a}} \pm 0.19$ & $62.3^{\mathrm{b}} \pm 0.33$ & $58.3 \mathrm{c} \pm 1.58$ \\
\hline $\mathrm{T}_{3}$ & $27.3^{\mathrm{b}} \pm 0.39$ & $24.0^{\mathrm{bc}} \pm 0.14$ & $36.3^{\mathrm{a}} \pm 0.13$ & $29.3^{\mathrm{a}} \pm 0.19$ & $62.8^{\mathrm{b}} \pm 0.33$ & $59.7 b \pm 0.19$ \\
\hline $\mathrm{T}_{4}$ & $29.7^{\mathrm{a}} \pm 0.19$ & $26.0^{\mathrm{a}} \pm 0.11$ & $36.3^{\mathrm{a}} \pm 0.17$ & $29.7^{\mathrm{a}} \pm 0.15$ & $63.4^{\mathrm{a}} \pm 1.00$ & $63.3 \mathrm{a} \pm 1.64$ \\
\hline $\mathrm{T}_{5}$ & $27.4^{\mathrm{b}} \pm 0.39$ & $25.3^{\mathrm{a}} \pm 0.19$ & $36.3^{\mathrm{a}} \pm 0.18$ & $29.3^{\mathrm{a}} \pm 0.18$ & $62.1^{\mathrm{b}} \pm 0.67$ & $59.3 b \pm 0.69$ \\
\hline LSD0.01 & 2.01 & 1.46 & 1.46 & 1.42 & 0.51 & 1.12 \\
\hline $\mathrm{CV} \%$ & 3.4 & 3.24 & 1.42 & 1.76 & 3.12 & 6.25 \\
\hline
\end{tabular}

Note: Values are means of three replicates \pm SE; Values in a column with having similar and dissimilar superscript letter(s) are significantly similar and different $(\mathrm{p}>0.01)$ respectively; Control $\left(\mathrm{T}_{1}\right)$, Cowdung $\left(\mathrm{T}_{2}\right)$, Annapurna organic fertilizer $\left(\mathrm{T}_{3}\right)$, $75 \%$ Annapurna organic fertilizer $+25 \%$ Vermicompost $\left(\mathrm{T}_{4}\right)$ and Vermicompost $\left(\mathrm{T}_{5}\right)$.

Table 2. Effect of different fertilizer on tuber yield of two potato varieties ${ }^{\mathrm{X}}$.

\begin{tabular}{|c|c|c|c|c|}
\hline \multirow{3}{*}{ Treatments } & \multicolumn{4}{|c|}{ Tuber yield } \\
\hline & \multicolumn{2}{|c|}{ kg per plot } & \multicolumn{2}{|c|}{ t.ha ${ }^{-1}$} \\
\hline & $\mathrm{V}_{1}$ & $\mathrm{~V}_{2}$ & $V_{1}$ & $\mathbf{V}_{2}$ \\
\hline $\mathrm{T}_{1}$ & $10.7^{b} \pm 0.39$ & $10.1^{b} \pm 0.34$ & $23.5^{\mathrm{cd}} \pm 0.48$ & $21.0^{\mathrm{b}} \pm 0.13$ \\
\hline $\mathrm{T}_{2}$ & $11.3^{\mathrm{b}} \pm 0.20$ & $11.2^{\mathrm{b}} \pm 0.35$ & $22.2^{\mathrm{d}} \pm 0.15$ & $23.5^{b} \pm 0.66$ \\
\hline $\mathrm{T}_{3}$ & $12.7^{\mathrm{ab}} \pm 0.11$ & $14.1^{\mathrm{a}} \pm 0.37$ & $26.0^{\mathrm{bc}} \pm 0.20$ & $28.3^{a} \pm 0.72$ \\
\hline $\mathrm{T}_{4}$ & $14.3^{\mathrm{a}} \pm 0.37$ & $13.7^{\mathrm{a}} \pm 0.05$ & $28.8^{\mathrm{a}} \pm 0.41$ & $27.7^{\mathrm{a}} \pm 0.13$ \\
\hline $\mathrm{T}_{5}$ & $12.8^{\mathrm{ab}} \pm 0.27$ & $11.2^{\mathrm{b}} \pm 0.29$ & $26.2^{b} \pm 0.42$ & $22.9^{\mathrm{b}} \pm 0.21$ \\
\hline LSD0.01 & 2.2 & 1.7 & 2.5 & 3.695 \\
\hline $\mathrm{CV} \%$ & 6.6 & 5.0 & 3.62 & 5.47 \\
\hline
\end{tabular}

Note: Values are means of three replicates \pm SE; values in a column with having similar and dissimilar superscript letter(s) are significantly similar and different $(\mathrm{p}>0.01)$ respectively; Control $\left(\mathrm{T}_{1}\right)$, Cowdung $\left(\mathrm{T}_{2}\right)$, Annapurna organic fertilizer $\left(\mathrm{T}_{3}\right), 75 \%$ Annapurna organic fertilizer $+25 \%$ Vermicompost $\left(\mathrm{T}_{4}\right)$ and Vermicompost $\left(\mathrm{T}_{5}\right)$.

Yield: Yield of potato varieties varied significantly among the treatments. In case of $\mathrm{V}_{1}$, maximum yield was found from $\mathrm{T}_{4}\left(14.3 \mathrm{~kg}\right.$ per plot and $\left.28.8 \mathrm{t}^{\mathrm{h} \mathrm{ha}^{-1}}\right)$ while minimum from $\mathrm{T}_{1}\left(10.7 \mathrm{~kg}\right.$ per plot and 22.2 t.ha $\left.{ }^{-1}\right)$ whereas for the $V_{2}$, maximum yield was found in $T_{3}\left(14.1 \mathrm{~kg}\right.$ per plot and 28.3 t.ha $\left.{ }^{-1}\right)$ and minimum was found 
from $\mathrm{T}_{1}\left(10.1 \mathrm{~kg}\right.$ per plot and $21.0 \mathrm{t}^{\mathrm{ha}} \mathrm{h}^{-1}$ ) (Table 2). $\mathrm{V}_{1}$ was found as more yielder variety than $\mathrm{V}_{2}$.

Grade wise tuber yield: Yield of different graded tuber was not varied significantly among the treatments in both varieties (except $\mathrm{V}_{1}: 28-55 \mathrm{~mm}$ ). Maximum yield was found in $\mathrm{T}_{4}$ at $28-55 \mathrm{~mm}$ graded tuber $\left(\mathrm{V}_{1}: 12.74 \mathrm{~kg}\right.$ per plot and $\mathrm{V}_{2}: 12.31 \mathrm{~kg}$ per plot) (Table 3). In this case $\mathrm{V}_{1}$ also found as the better performer than $\mathrm{V}_{2}$.

Table 3. Effect of different fertilizer on grade wise tuber yield of two potato varieties ${ }^{\mathrm{X}}$.

\begin{tabular}{|c|c|c|c|c|c|c|}
\hline \multirow{3}{*}{ Treatments } & \multicolumn{6}{|c|}{ Yield (kg per plot) according to different tuber grade } \\
\hline & \multicolumn{2}{|c|}{$<28 \mathrm{~mm}$} & \multicolumn{2}{|c|}{$28-55 \mathrm{~mm}$} & \multicolumn{2}{|c|}{$>55 \mathrm{~mm}$} \\
\hline & $\mathbf{V}_{1}$ & $\mathbf{V}_{2}$ & $\mathbf{V}_{1}$ & $\mathbf{V}_{2}$ & $\mathbf{V}_{1}$ & $\mathbf{V}_{2}$ \\
\hline $\mathrm{T}_{1}$ & $0.65^{\mathrm{a}} \pm 0.07$ & $0.81^{\mathrm{a}} \pm 0.09$ & $9.30^{\mathrm{d}} \pm 0.42$ & $9.02^{\mathrm{a}} \pm 0.31$ & $0.73^{\mathrm{a}} \pm 0.06$ & $0.49^{\mathrm{a}} \pm 0.11$ \\
\hline $\mathrm{T}_{2}$ & $0.75^{\mathrm{a}} \pm 0.05$ & $1.02^{\mathrm{a}} \pm 0.06$ & $9.92^{\mathrm{cd}} \pm 0.25$ & $10.12^{\mathrm{a}} \pm 0.79$ & $0.66^{\mathrm{a}} \pm 0.11$ & $0.61^{\mathrm{a}} \pm 0.10$ \\
\hline $\mathrm{T}_{3}$ & $0.91^{\mathrm{a}} \pm 0.09$ & $0.74^{\mathrm{a}} \pm 0.07$ & $11.86^{\mathrm{ab}} \pm 0.45$ & $12.31^{\mathrm{a}} \pm 0.53$ & $0.57^{\mathrm{a}} \pm 0.02$ & $0.69^{\mathrm{a}} \pm 0.06$ \\
\hline $\mathrm{T}_{4}$ & $0.78^{\mathrm{a}} \pm 0.04$ & $0.95^{\mathrm{a}} \pm 0.06$ & $12.74^{\mathrm{a}} \pm 0.66$ & $11.48^{\mathrm{a}} \pm 0.41$ & $0.41^{\mathrm{a}} \pm 0.10$ & $0.74^{\mathrm{a}} \pm 0.09$ \\
\hline $\mathrm{T}_{5}$ & $0.64^{\mathrm{a}} \pm 0.13$ & $0.57^{\mathrm{a}} \pm 0.14$ & $10.67^{b c} \pm 0.72$ & $10.43^{\mathrm{a}} \pm 0.59$ & $0.44^{\mathrm{a}} \pm 0.13$ & $0.53^{\mathrm{a}} \pm 0.13$ \\
\hline LSD0.01 & 0.71 & 0.68 & 1.34 & 3.92 & 0.83 & 0.74 \\
\hline $\mathrm{CV} \%$ & 14.63 & 10.45 & 14.42 & 11.42 & 13.96 & 12.94 \\
\hline
\end{tabular}

Note: Values are means of three replicates \pm SE; values in a column with having similar and dissimilar superscript letter(s) are significantly similar and different $(\mathrm{p}>0.01)$ respectively; Control $\left(\mathrm{T}_{1}\right)$, Cowdung $\left(\mathrm{T}_{2}\right)$, Annapurna organic fertilizer $\left(\mathrm{T}_{3}\right)$, $75 \%$ Annapurna organic fertilizer $+25 \%$ Vermicompost $\left(\mathrm{T}_{4}\right)$ and Vermicompost $\left(\mathrm{T}_{5}\right)$.

\section{DISCUSSION}

The results showed seed potato performed differently on growth and yield to different organic fertilizers. Nitrogen content increases in soil by the application of organic fertilizers may stimulate the faster plant growth that lead to more yield (Nogales et al. 2005). The stimulation of the plant growth in organic fertilizers arises by the presence of the phytohormones (Nogales et al. 2005, Smith et al. 2014). Our results showed that additional application of organic fertilizers with inorganic fertilizers increases the total tuber yield also different graded tuber. Integrated nutrient management by the application of both inorganic fertilizers and organic manures increases the different grades tuber production (Kumar et al. 2008, 2011, Das et al. 2009) and total tuber yield (Kumar et al. 2001, Raghav \& Kamal 2008). Yield of tuber increases due to the availability of N, P and K contents in soil through the application of organic manures (Kumar et al. 2008, Baishya 2009, Zaman et al. 2011). The maximum advantages from applications of additional organic fertilizers with recommended doses of inorganic fertilizers might be found and i.e., to enhance uptake of fertilizer, to increased soil physical and chemical properties. Besides, by providing macro and micronutrient organic manure improve crop production. Potato yielded more tuber from manure application along with inorganic fertilizers (Johnston 1986, Nyiraneza \& Snapp 2007, Bereez et al. 2005, Alam et al. 2007, Gruhn et al. 2000, Daniel et al. 2008). In our study potato tuber size $<28 \mathrm{~mm}, 28-55 \mathrm{~mm},>55 \mathrm{~mm}$ were considered as undersized, marketable and oversized as similar to Chilephake \& Trautz (2014). In case of the 28-55 mm grade tuber, all the treatments had significant effect in asterix but it was not found any significant effect in diamant variety. Significant difference for grade wise tuber yield was found among different genotypes (Bhardwaj et al. 2008) and different treatments (Banjare et al. 2014, Chilephake \& Trautz 2014) while non-significant difference was also found by Banjare et al. (2014).

\section{CONCLUSION}

Both the asterix and diamant variety were very popular to farmers in Bangladesh. It was found that asterix was better than diamant variety considering tuber yield. The asterix variety showed best performance in $\mathrm{T}_{4}(75 \%$ Annapurna organic fertilizer $+25 \%$ Vermicompost) with BARI recommended inorganic fertilizers among the treatments used in the study. Annapurna organic fertilizer $\left(\mathrm{T}_{3}\right)$ was found as the best treatment for diamant. It is recommended to use BARI recommended inorganic fertilizers with $\mathrm{T}_{4}$ treatment for asterix and $\mathrm{T}_{3}$ for diamant. But further research is suggested using combination of organic and inorganic fertilizers in different areas of Bangladesh. From the results of the current study it can be concluded that use of the organic fertilizers with BARI recommended inorganic fertilizers can improve the tuber yield of potato.

\section{ACKNOWLEDGEMENT}

Authors are highly grateful to Bangladesh Agriculture Development Corporation (BADC) for providing the entire experimental facilities. 


\section{REFERENCES}

Alam MN, Jahan MS, Ali MK, Ashraf MA \& Islam MK (2007) Effect of vermicompost and chemical fertilizers on growth, yield and components of potato in barind soils of Bangladesh. Journal of Applied Science Research 3(12): 1879-1888.

Amede T, German L, Rao S, Opondo C \& Stroud A (2006) Integrated natural resource management in practice: Enabling communities to improve mountain livelihoods and landscapes. In: Proceedings of the African Highland Initiative Conference, October, 2004, pp. 12-15.

Arora S (2008) Balanced nutrition for sustainable crop production. Krishi World (Pulse of Indian Agriculture), pp. $1-5$.

Atiyeh R, Subler S, Edwards C, Bachman G, Metzger J \& Shuster W (2000) Effects of vermicomposts and composts on plant growth in horticultural container media and soil. Pedobiologia 44(5): 579-590.

Baishya LK (2009) Response of potato varieties to organic and inorganic sources of nutrients, Ph.D. Thesis. Visva-Bharati University, West Bengal, India, pp. 99-102.

Banjare S, Sharma G \& Verma S K (2014) Potato Crop Growth and Yield Response to Different Levels of Nitrogen under Chhattisgarh Plains Agro-climatic Zone. Indian Journal of Science and Technology 7(10): 1504-1508.

BARI (2011) A hand book for Agricultural technology (Krishi Projukti Hatboi). Bangladesh Agricultural Research Institute, Joydevpur, Gazipur. Bangladesh, pp. 307-308.

Bayite-Kasule S (2009) Inorganic Fertilizer in Uganda: Knowledge Gaps, Profitability, Subsidy, and Implications of a National Policy. International Food Policy Research Institute (IFPRI).

Bereez K, Kismanyott T \& Debreczeni K (2005) Effects of organic matter recycling in long term fertilization trials and model pot experiments. Communications in Soil Science and Plant Analysis 36(1-3): 192-202.

Bhardwaj V, Pandey S K, Manivel P, Singh S V \& Kumar D (2008) Stability of indigenous and exotic potato processing cultivars in Himachal Pradesh hills. In: Proceedings of the Global Potato Conference, Dec. 9-12, New Delhi, pp. 22-22.

Boke S (2014) Effect of organic and inorganic fertilizer application and seedbed preparation on potato yield and soil properties on alisols of Chencha. International Journal of Natural Sciences Research 2(8): 123-132.

Champouret N (2010) Functional genomics of phytophthora infestans effectors and Solanum resistance genes, Ph.D. Thesis. Wageningen University, Wageningen, Netharland.

Chilephake U \& Trautz D (2014) Tuber development rates of six potato varieties in organic farming in Osnabrück, Germany. In: Proceedings of the $4^{\text {th }}$ ISOFAR Scientific Conference: 'Building Organic Bridges', at the Organic World Congress, October 13-15. Istanbul, Turkey, pp. 383-386.

Daniel M, Pant LM \& Nigussie D (2008) Effect of integrated nutrient management on yield of potato and soil nutrient status of Bako, West Shoa. Ethiopian Journal of Natural Resources 10: 85-101.

Das PP, Sarkar A \& Zamen A (2009) Response of organic and inorganic sources of nutrients on growth and yield of potato in Gangetic alluvial plains of west Bengal. In: Proceedings of $96^{\text {th }}$ Indian Science Congress, part-II (Abstract), 3-7 ${ }^{\text {th }}$ January at NEHU, Shillong, Meghalaya.

Fageria NK, Baligar VC \& Jones CA (1997) Growth and mineral nutrition of field crops, $2^{\text {nd }}$ Edition. Marcel Dekker Inc., New York.

Ferdoushi SN, Farooque AM \& Alam MS (2010) Effects of organic and inorganic fertilizer management practices and mulch on the growth and yield of potato. Journal of Agroforestry and Environment 3(2): 175178.

Gomez KA \& Gomez AA (1984) Statistical Procedure for Agricultural Research, $2^{\text {nd }}$ Edition. International Rice Research Institute, A Willey International Science Publisher, pp. 28-192.

Gruhn P, Goletti F, \& Yudelman M (2000) Integrated nutrient management, soil fertility and sustainable agriculture: Current issues and future challenges. IFPRI, Food, Agriculture and the Environment Discussion, Paper No. 32, Washington D.C.

Johnston AE (1986) Soil organic matter, effects on soils and crops. British Society of Soil Science 2(3): 97-105.

Kumar M, Baishya LK, Ghosh DC \& Gupta VK (2011) Yield and quality of potato (Solanum tuberosum) tubers as influenced by nutrient sources under rainfed condition of Meghalaya. Indian Journal of Agronomy 56(3): 260-266.

Kumar M, Jadav MK \& Trehan SP (2008) Contributing of organic sources to potato nutrition at varying nitrogen levels. Global Potato Conference, 9-12 December, New Delhi, India.

www.tropicalplantresearch.com 
Kumar V, Jaiswal RC \& Singh AP (2001) Effect of biofertilizers on growth and yield of potato. Journal of the Indian Potato Association 28: 6-7.

Munroe G (2007) Manual of on-farm vermicomposting and vermiculture. Organic Agriculture Centre of Canada, pp. 1-56.

Nogales R, Cifuentes C \& Benitez E (2005) Vermicomposting of winery wastes: a laboratory study. Journal of Environmental Science and Health Part B 40(4): 659-673.

Nyiraneza J \& Snapp S (2007) Integrated management of inorganic and organic nitrogen and efficiency in potato systems soil fertility \& plant nutrition. Soil Science Society of America Journal 71(5): 1508-1515.

Raghav M \& Kamal S (2008) Organic farming technology for higher and eco-friendly potato production in tarai region of Uttrakhand. Global Potato Conference, 9-12 December, New Delhi, India.

Rajesh C, Reddy KS, Naidu M \& Ramavatharam N (2003) Production and evaluation of composts and vermicomposts from solid organic wastes. Asian Journal of Microbiology Biotechnology and Environmental Sciences 5(3): 307-311.

Roy SK, Sharma RC \& Thehan SP (2001) Integrated nutrient management by using Farmyard manure and fertilizers in potato-sunflower-paddy rice rotation in the Punjap. The Journal of Agricultural Science 137: 271-278.

Sharma A, Sharma R, Sonia S \& Sharma JJ (2003) Influence of integrated use of nitrogen, phosphorus, potassium and farmyard manure on yield-attributing traits and marketable yield of carrot (Daucus carota) under high hills dry temperate conditions of North-Western Himalayas. Indian Journal of Agricultural Science 73(9): 500-504.

Smith J, Abegaz A, Matthews RB, Subedi M, Orskov ER, Tumwesige V \& Smith P (2014) What is the potential for biogas digesters to improve soil fertility and crop production in Sub-Saharan Africa? Biomass and Bioenergy 70: 58-72.

Verzaux E (2010) Resistance and susceptibility to late blight in Solanum: Gene mapping, cloning and stacking, Ph.D. Thesis. Wageningen University, Wageningen, Netharland.

Visser RGF, Bachem CWB, de Boer JM, Bryan GJ, Chakrabati, Feingold S, Gromadka R, van Ham RCHJ, Huang S, Jacobs JME, Kuznetsov B, de Melo PE, Milbourne D, Orjeda G, Sagredo B \& Tang X (2009) Sequencing of the potato genome: outline and first results to come from the elucidation of the sequences of the world's third most important food crop. American Journal of Potato Research 86: 417-429.

Zaman A, Sarkar A, Sarkar S \& Devi WP (2011) Effect of organic and inorganic sources of nutrients on productivity, specific gravity and processing quality of potato (Solanum tuberosum). Indian Journal of Agricultural Sciences 81(12): 1137-1142. 